\title{
THE VISITORS' PERCEPTION OF AUTHENTICITY AT THE MUSEUMS: ARCHAEOLOGY VERSUS MODERN ART
}

Juan Gabriel Brida ${ }^{\mathrm{a},} ;$ Marta Disegna $^{\mathrm{b}} ;$ Raffaele Scuderi ${ }^{\mathrm{c}}$

\begin{abstract}
a Tourism Economics at the School of Economics and Management - Free University of Bolzano, Piazza dell'Università, 39100 Bolzano, Italy; 'Applied Economics at the School of Economics and Management - Free University of Bolzano, Piazza dell'Università, 39100 Bolzano, Italy; 'Economics at the School of Economics and Management - Free University of Bolzano, Piazza dell'Università, 39100 Bolzano, Italy
\end{abstract}

(Received 7 June 2012; final version received 15 October 2012)

\section{Abstract}

The aim of this paper is to analyse quantitatively the visitors' perception of authenticity in two different types of museums: archaeology versus modern and contemporary art. The research is based on 1,288 questionnaires collected from June to September 2011 among the visitors of the South Tyrol Museum of Archaeology (ÖTZI) in Bolzano and the Museum of Modern and Contemporary Art (MART) in Trento-Rovereto. Logit models were used in order to estimate the set of independent variables that significantly influence both the perception of the authenticity and the "virtual" choice between the two types of museums considered. The results suggested that the authenticity perception was related to peculiar authenticity-related factors and by specific socio-demographic characteristics of the interviewee, although some common elements emerge. In particular, ÖTZI authenticity is linked to its uniqueness in the world, whereas MART visitors relate authenticity to the museum's building and the perception that it was not just a tourist attraction. The empirical evidence confirms the well-known concept that authenticity perception is a dynamic experience, depending on the peculiar characteristics of the attraction analysed.

Keywords Authenticity, Museums, Logit Model.

\footnotetext{
*Corresponding author. Email: juangabriel.brida@unibz.it
} 


\section{Introduction}

Cultural tourism is defined as "the movement of persons to cultural attractions away from their normal place of residence with the intention to gather new information and experiences to satisfy their cultural needs" (Bonet, 2003). Among the different activities which may be considered part of the cultural tourism field, museums are the most popular attractions, usually followed by art galleries and monuments (McKercher, 2004). Their role in culture is not only related to the creation of new understandings of the past, but also the reaffirmation of an identity in time and space (McIntosch and Prentice, 1999) that is often unavailable elsewhere (Tufts and Milne, 1999; Graburn, 1998, 1983). Furthermore, especially in a period when mass tourism was still relatively new, museums were considered by visitors as an intellectual experience, i.e. a journey of the mind (Kirshenblatt -Gimblett, 1998).

As stated in the code of ethics formulated by the American Association of Museums (AAM, 2000), the present scope of museums is to provide a service to the public, by means of collecting, preserving, exhibiting, and educating with materials that are owned, borrowed, and/or fabricated for these ends (AAM, 2000). This is functional to make them "part of a universal cultural system for the dissemination of knowledge and experience" (Herreman, 1998). Regarding the public role of museums, Bennett (1995) noted that despite being structured and available to all visitors, museums appeal to a certain sector of the public, which is able to participate fully in the experience on a cultural level.

When the visit is felt as authentic, museums are perceived differently than being only "agents of conservation" (Harrison, 2005; Lennon and Graham, 2001; Prentice, 2001). As McIntosch and Prentice (1999) suggested, "enculturation is more than the internalization of text and categories; instead it is more a holistic experience, interpersonal, and comprising thoughts, feelings, and emotions".

Authenticity is not a tangible asset, but rather a judgement or value placed on what is assessed (Xie and Wall, 2002). It is not a fixed attribute since it is negotiated among a variety of stakeholders (Yang and Wall, 2009). This implies that the concept of authenticity is multifaceted since it is in a constant state of flux (McKercher and Du Cros, 2002). This means that current and possibly future researchers do not generally accept one unified definition of the concept. 
Therefore it is not surprising that each author proposes her own view (Rickly-Boyd, 2012; Chhabra, 2012, 2008) and analytical approaches are multiple. Reasons for this dynamism have to be ascribed to both the particular characteristics and perceptions of the audience (see Chhabra, 2008), and the characteristics of the specific types of cultural attractions under analysis. Cultural events (such as festivals, works of art, rituals, or other attractions related to food, dress, language and religion) or other cultural attractions such as museums, galleries, architecture, heritage sites, and artistic performances might produce different experiences in visitors (Stylianou-Lambert, 2011). Therefore, it is often difficult to make generalizations and it would be more appropriate to evaluate the authenticity concept in specific case studies. As a result, studies have generally analysed the concept of authenticity from a qualitative perspective with limited research conducted from a quantitative analysis perspective.

For a long time visitors of cultural attractions were treated as an homogeneous mass of people. However, the tendency of the recent tourist literature is to consider them as a heterogeneous group with different characteristics, perceptions, and needs (Schouten, 2007; Hughes, 2002). Brida et al. (2012a) empirically showed that tourists and local residents have a significantly different perception of authenticity of the same cultural event in a study on a Christmas Market in Northern Italy. Stylianou-Lambert (2011) stressed that visitors might seek different experiences in an art museum, a history museum, an opera, or an outdoor festival. Other studies showed that tourists who visit art museums present different socio-demographic characteristics (in particular regarding the level of education, income, and occupation) than those who engaged in festivals, musical activities, theme parks, amusements parks, local fairs, and events (Kim et al., 2007; Bennett, 1994; Schuster, 1991). Furthermore, culture (including ethnic origins and race) and leisure activities such as museums and other cultural attractions may influence tourists' lifestyles (Correia et al., 2011).

Most tourism research gave the common label of "museum" to stamps art, history, science, and even children's museums. Such heterogeneity shows that "all museums are products of their particular cultural and historical experiences" (MacDonald and Alsford, 1995). The museums have a double effect: ordinary objects become extraordinary when placed in museum settings, and the museum experience itself becomes a model for experiencing life outside its walls (Kirshenblatt-Gimblett, 1998). Therefore, museums offer a wide range of attractions to appeal to a variety of types of tourist (Dicks, 2003). For these reasons research should consider cultural attractions, 
and particularly museums, separately according to their subject matter and experiences offered (Stylianou-Lambert, 2011; Correia et al., 2011).

Taking into consideration the heterogeneity of the authenticity concept, the visitors and the museums, this paper investigates the perception of authenticity in two different types of museums, contributing in this way to the cultural tourism literature on authenticity analysis.

Differences and similitudes in the authenticity perceptions are studied on visitors of an archaeological and a modern and contemporary art museum. The paper adopts two different approaches, both making use of Logit models. The first studies the factors that are likely to influence authenticity and compares results between the two museums. The second one tests whether a set of covariates including authenticity proxies influence the museum visit, and if these relationships vary within the groups of those who explicitly declare they have considered the museums generally as authentic or inauthentic.

The data used for this study were collected from ad-hoc surveys conducted from June to September 2011 at the two main museums of the two provinces of the Trentino-South Tyrol region (Trento and Bolzano). The South Tyrol Museum of Archaeology is located in the Province of Bolzano and hosts the permanent exhibition of the mummy Ötzi, "the Iceman". The Museum of Modern and Contemporary Art is instead located in the province of Trento and hosts one of the most important collections in Italy for this artistic period.

The paper is organized as follows. Section 2 briefly reviews the literature on the concept of authenticity for cultural attractions. Section 3 illustrates the main characteristics of the two museums, the survey method and the econometric model. Section 4 reports both descriptive statistics and empirical results. Section 5 discusses the findings, draws conclusions also in terms of practical implications for policymakers and private operators, and illustrates future research perspectives.

\section{The concept of authenticity}

Understanding the concept of authenticity is crucial for marketing and managing cultural heritage sites. It is universally recognized as one of the main factors motivating tourists to travel far away from home and for long period (Kolar and Zabkar, 2010; Yeoman et al., 2007; Naoi, 2004; Apostolakis, 2003; Cohen, 1988; MacCannell, 1973; Brida et al., 2012c). Despite this, the most recent literature on tourism authenticity does 
not show a unified view, and various approaches are proposed leading to different and often contradictory results (Rickly-Boyd, 2012; Chhabra, 2012; Kolar and Zabkar, 2010).

Following Wang (1999), a cultural tourism product (for example festivals, rituals, or works of art) can be considered authentic when it is made "by local people according to custom or tradition". Traditional culture becomes more genuine, real, and unique if wrapped in authenticity (Sharpley, 1994) and "the presence of the original is the prerequisite of the concept of authenticity" (Benjamin, 1968). Handler and Saxton (1988) observe that "an authentic experience [...] is one in which individuals feel themselves to be in touch both with a 'real' world and with their 'real' selves". In particular, Selwyn (1996) distinguished authenticity as "knowledge" (namely "cool" authenticity) and "feeling" (namely "hot" authenticity), depending on whether it concerns the "real" world or the "real" self and society respectively.

MacCannell (1973) introduced the concept of "staged authenticity" in the context of ethnic tourism (Chhabra et al., 2003). In order to sell a fascinating tourism package, tourees (hosts) put their culture (including themselves) on sale and "the degree that this packaging alters the nature of the product, the authenticity sought by the visitor becomes 'staged authenticity' provided by the touree" (MacCannell, 1973). The meaning of MacCannell's definition is that tourists are often provided with experiences or performances that are theatrical or orchestrated in order to meet their expectation. These experiences are usually superficial, featuring only the "front stage" area of a culture without capturing its "back stage". This implies that tourists have only the illusion to be in contact with the "real" or "genuine" foreign culture. Cohen (1988) offered the concept of "emergent authenticity" referring to the authentication process to which a culture can be subject: "a cultural product, or trait thereof, which is at one point generally judged as contrived or inauthentic may, in the course of time, become generally recognized as authentic" (Cohen, 1988). From then on, the concept of authenticity has been interpreted in different ways: it was defined as value (Olsen, 2002), motivational factor (Leigh et al., 2006; Naoi, 2004), "claim" (Peterson, 2005), perception (Cohen, 1988), and choice people make (Steiner and Reisinger, 2006).

Wang (1999) classified the authenticity concept into three groups: objective, constructive, and existential. Rickly-Boyd (2012) added to Wang's classification the group of "postmodern", whereas Chhabra (2012) considered two groups in addition (negotiated and theoplacity). Lau (2010) revisited the original view of objective 
authenticity and proposed a social realist concept. Rickly-Boyd (2012) underlined the importance to explore the authenticity concept in relation to the Benjaminian idea of "aura". Benjamin $(1968 ; 2008)$ suggested in fact that "the authenticity of a thing is the quintessence of all that is transmissible in it from its origins on, ranging from its physical duration to the historical testimony relating to it", where "aura" is an experience, an engagement, defined as a "strange tissue of space and time: the unique apparition of a distance, however near it may be".

Within this wide set of approaches, MacCannell's work (1973) can still be considered relevant: "touristic consciousness is motivated by its desire for authentic experiences, and the tourist may believe that he is moving in this direction, but often it is very difficult to tell for sure if the experience is authentic". In fact, defining what authenticity is and whether an experience can be considered authentic or not is a complex matter (Rickly-Boyd, 2012). At the same time the concept of authenticity is became of primary relevance for marketing (Brown et al., 2003) because it is present "in the minds of tourists, tourist brokers, and members of host communities" (Belhassen and Calton, 2006). Consumers interpret authenticity in different ways, but the notion offers the basis for successful consumption of cultural offerings and leads to future cultural behavioural intentions (Ramkissoon and Uysal, 2011; McIntosh and Prentice, 1999). Therefore, distinguishing the fields the concept refers to can be an important step towards its definition.

\subsection{Museums and authenticity}

Heritage tourism has utilized nostalgic images to attract tourists who look for the past and history for pleasure and entertainment. As Lowenthal (2005) commented, "If the past is a foreign country, nostalgia has made it the foreign country with the healthiest tourist trade of all". People going to museums or other historic places are primarily seeking an image of the past which is perceived as very distant (Lowenthal, 2005) rather than an authentic historical experience (Schouten, 2007).

The concept of the authenticity was originally introduced in the literature as strictly related to museums, "where persons expert in such matters test whether objects of art are what they appear to be or are claimed to be, and therefore worth the price that is asked for them - or, if this has already been paid, worth the admiration they are being given" (Trilling, 1972). The translation of the concept into the tourism field was quite 
natural but almost exclusively related to tourist experience. Museums should aim to create a peculiar experience of the visit, which in Hastrup and Hervik's (1994) view has to be holistic, interpersonal, emotional, and of course authentic. The perception of authenticity in a museum is complex also because both authentic and inauthentic experiences concur in equal parts in being part of the visitor experience (Hall, 2007). This challenges Benjamin's view of the original as a prerequisite for authenticity (Hede and Thyne, 2010). In Carnegie and McCabe's (2008) words, the main consequence of this process may be the evolution of museums from being agents of education to places for "serious leisure". Nevertheless, authenticity still remains a measure of a museum's distinctiveness (Baudrillard, 1983). As Handler (1986) suggested, the search for authentic experiences coincides with the search for "the unspoiled, pristine, genuine, untouched and traditional". But these feelings are an interpretation of genuineness and of the visitors' desire for the experience (Spooner, 1986). A museum can produce an authentic experience depending on the type of its exhibition, the exposition of the materials, its building and the feelings it may transmit during the visit.

Pine and Gilmore (2007) suggested that there are three different levels to be taken into consideration when dealing with museums and authenticity: artifacts, edifices and encounters. There is a long controversy in the tourism literature on what makes artifacts authentic or not, but what is sure is that museums only contain real artifacts. In general, authenticity is not an inherent quality of an object or experience but something ascribed to it (Rubridge 1995). Objects displayed in museums and the information provided by these objects are in general perceived by the visitors to be genuine. Therefore, even if "every relic displayed in a museum is a fake in that it has been wrenched out of its original context" (Lowenthal, 1990) the museum can generate an authentic experience. The museums are seen as product of the societies that support them, a selective treasure house reflecting past and present power relations (Macdonald and Fyfe, 1996). In some cases, the edifices of museums where their objects reside can render all the objects that lie within and the whole museum itself authentic. This is the case of the Guggenheim Museum of Bilbao and of the MART Museum of Rovereto. Certainly, buildings are also objects that are constructed to give value to the museums. Finally, the encounter of the visitor with both the edifice and artifacts produce an experience that can be viewed as authentic or inauthentic.

As for souvenirs and handicrafts sold in the shops of museums and heritage centres, the visitors "want a genuine piece to take home" because they are "bored with the junk for 
sale on the streets and on the tourist markets" (Schouten, 2007). In doing this, museums and heritage centres must be careful to not fall into the dilemma of authenticity proposed by Culler (1988): "to be experienced as authentic it must be marked as authentic, but when it is marked as authentic it is mediated, a sign of itself, and hence lacks the authenticity of what is truly unspoiled, untouched by mediating cultural codes". In fact, the visitors want the souvenirs to be labelled "authentic native crafts produced by certified natives using guaranteed original materials and archaic techniques", but such markers are put there for tourists, certifying that the souvenir is a touristic object. Therefore, it is fundamental to offer visitors high quality products, as suggested by Schouten (2007), and museums and heritage centres can offer this because they have the original objects and the expertise.

\section{Case study, data and methodology}

\subsection{The museums}

The research involved the two main museums of Trentino-South Tyrol region, Northern Italy, that differ in terms of typology. The South Tyrol Museum of Archaeology (shortened to ÖTZI) is located in Bolzano, the main city of South Tyrol. Opened in March 1998, it hosts the permanent exhibition of Ötzi, 'the iceman', a mummy from the Neolithic period of a man living in the region more than 5,000 years ago. Ötzi was accidently discovered in September 1991 on Ötztal Alps by two German hikers. At a first sight it was thought to be an unfortunate victim of the mountains. Later scholars discovered that it was one of the oldest mummies in the world. Due to its good preservation status and the presence of several belongings it has attracted researchers from around the world, to make investigations about the living conditions of ancient men. The mummy can be seen by museum visitors from a window on the so-called 'Iceman Box', a refrigerator that keeps Ötzi at particular temperature and humidity conditions. This extraordinary and unique discovery in the world is the main cultural magnet of the city of Bolzano. (see Brida et al., 2012d)

The Museum of Modern and Contemporary Art (shortened to MART) is the second museum under consideration. MART is placed in Trento and Rovereto, the two main cities of the province of Trento. The main building is located in Rovereto, the hometown of the futurist artist Fortunato Depero, and was designed by the Swiss 
architect Mario Botta in the late 1980s. Therefore, this building itself constitutes a touristic attraction and contributes to the authenticity perception of the visitors (see Pine and Gilmore, 2007). The museum hosts a permanent collection of modern art, where works are displayed on a rotating basis, and temporary exhibitions. It holds the most important collections in Italy concerning different artistic genres of modern and contemporary art, in particular futurism. As pointed out by Brida et al. (2012b), the idea of a museum for modern and contemporary art was born in the late 1970s against the background of industrial and unemployment crisis. The museum generates revenues from tickets sales, merchandising, sponsors and publishing that cover $24 \%$ of total running costs. The remaining $76 \%$ is publicly funded by the Autonomous Province of Trento.

\subsection{Research design}

The research is based on a survey conducted from June to September 2011 among the visitors of the ÖTZI and MART museums. A total of 1,288 interviews were successfully collected almost evenly (46\% for MART, 54\% in the ÖTZI museum). In order to encourage cooperative behaviour, respondents were informed that the research had exclusively scientific aims, and that impartiality in the data analysis was guaranteed. Furthermore, a pilot survey was carried out to test the questionnaire before conducting the full survey, in order to avoid bias related to its structure and wording. Interviews were held with visitors exiting the museums after their visit, in selected working and weekend days of the four months analysed, and during different time periods of the day. Only one person per travel party was selected. The questionnaires were anonymous and self-administered in three languages (Italian, German and English) and a research team member was present in order to solve questions or doubts that emerged among interviewers. The convenience sampling method was adopted as there was no sufficient information on the characteristics of visitors of the museums in order to apply a probabilistic design.

The questionnaire was structured in three sections (see Table 1). The first concerned information related to the visit to the museum. Section 2 included trip-related characteristics whereas the third section was related to socio-economic variables such as gender, age, education, occupation, and income. 
Table 1. Structure of the questionnaire.

\begin{tabular}{|c|c|c|}
\hline Sections & Object & Description \\
\hline I & $\begin{array}{l}\text { Museum } \\
\text { information }\end{array}$ & $\begin{array}{l}\text { Repeat visiting; number of museums visited in the last year; push } \\
\text { factors; ; rating of factors that describe the } \text { visit }^{* *} \text {; shopping } \\
\text { expenditure at the museum; authenticity perception }{ }^{*} \text {. }\end{array}$ \\
\hline II & Trip information & $\begin{array}{l}\text { Purpose of the trip; number of nights, expenditure per night and type } \\
\text { of accommodation used by tourists; expenditure per day for different } \\
\text { items. }\end{array}$ \\
\hline III & $\begin{array}{l}\text { Interviewees' } \\
\text { profile }\end{array}$ & $\begin{array}{l}\text { Some socio-demographic and economic characteristics of interviewees } \\
\text { and their families. }\end{array}$ \\
\hline
\end{tabular}

\subsection{Logit model}

The Logit model was used in order to test the significance, the verse, and the intensity of a set of independent variables in influencing a dichotomous dependent variable. In authenticity literature only the work by Brida et al. (2012a) adopts logistic regression in analysing the different perceptions of tourists and local residents. The study was divided into two parts. The first tests whether a set of variables influenced the probability of perceiving the museum as authentic. The second part is aimed at studying how proxies of authenticity and a set of other covariates affected the probability of visiting the museums. Accordingly two dependent dichotomous variables $\left(\mathbf{y}_{j}, j=1,2\right)$ were defined. The first dependent variable $\left(\mathbf{y}_{1}\right)$ reports whether the $i$ th respondent $(i=1, \ldots$, $N$, where $N$ is the sample size) perceived the museum as authentic $\left(y_{1 i}=1\right)$ or inauthentic $\left(y_{1 i}=0\right)$. Results on three subsets are compared, that is: the whole sample; MART's visitors; and ÖTZI's visitors. The second dependent variable $\left(\mathbf{y}_{2}\right)$ indicates whether the $i$ th respondent visited MART $\left(y_{2 i}=1\right)$ or ÖTZI $\left(y_{2 i}=0\right)$. Also in this case three subsets were tested, that is: the whole sample; people perceiving the museum as authentic; and visitors who reported that the museum was inauthentic.

When the dependent variable is dichotomous the Logit model is appropriate. It is a widely accepted statistical method in modelling dichotomously assessed dependent variables (Tsaur et al., 2002). An alternative model is the Probit whose results are very similar to those obtained through the Logit (Wooldridge, 2001). However, the Logit has the advantage that its results are interpretable in terms of Odds expressing the propensity of the dependent variable to assume the value 1. The Logistic regression model can be expressed as: 
$P\left(y_{i}=1\right)=\frac{\exp \left(\alpha+\beta^{\prime} x_{i}\right)}{1+\exp \left(\alpha+\beta^{\prime} x_{i}\right)}$

where $\alpha$ is the intercept, $\beta$ is a $K$-dimensional vector of parameters and $x$ is a $(K+1)$ dimensional vector of explanatory variables for the $i$ th observation. The estimated coefficients of each independent variable do not have a direct interpretation as in linear regression model, due to nonlinearities in the relationship. Logistic regression (equation 1) can be linearized through the Logit transformation. This transformation is simply the natural logarithm of the $O d d s$, i.e. the ratio between the probability of an event to occur and the probability it won't happen, calculated as follows:

$$
\frac{P\left(y_{i}=1\right)}{1-P\left(y_{i}=1\right)}=\exp \left(\alpha+\beta^{\prime} x_{i}\right)
$$

This implies that for each explanatory variable $x_{k}$, the term $\exp \left(\beta_{k}\right)$ is the change in the Odds (usually called Odds Ratio) for a unit increase in $x_{k}$, holding other variables constant. In the case of a dichotomous variable this term must be interpreted as the variation in the $O d d s$ in relation to the reference category.

\section{Sample description}

Significance in differences between subsets of the sample was tested. With this aim the sample of 1,288 visitors was divided between the groups mentioned in Section 3.3: MART vs. ÖTZI visitors, and perceivers of authenticity vs. inauthenticity.

Table 2 compares socio-demographic and economic characteristics of the interviewees and their families. Men seemed to be more attracted by ÖTZI and considered the museum as authentic more frequently than women. In comparison to ÖTZI, MART was more attractive for groups, visitors with a high educational level, retired or in other occupation (student, housewife, teacher, etc.). MART interviewees came from neighbour areas (i.e., North-East of Italy) more frequently than ÖTZI, and their households owned a lower income (less than €50,000). Wealth discriminated significantly also between those who perceive the museum as authentic and inauthentic. 
Table 2. Socio-demographic and economic characteristics of the sample.

\begin{tabular}{|c|c|c|c|c|c|c|}
\hline & MART & ÖTZI & $p$-value & Authentic & Inauthentic & $p$-value \\
\hline Male (\%) & 44.05 & 51.33 & $* * *$ & 49.00 & 42.16 & $*$ \\
\hline Age (mean) & 44.29 & 44.32 & & 44.38 & 42.93 & \\
\hline University (\%) & 82.58 & 68.45 & $* * *$ & 76.22 & 73.89 & \\
\hline Origin of visitors (\%) & & & $* * *$ & & & \\
\hline Abroad & 3.19 & 18.74 & & 12.15 & 8.37 & \\
\hline Germany & 3.70 & 34.70 & & 19.54 & 18.23 & \\
\hline Centre/South of Italy & 9.58 & 14.93 & & 13.00 & 10.83 & \\
\hline North-East of Italy & 40.34 & 12.15 & & 25.52 & 25.62 & \\
\hline North-West of Italy & 13.78 & 14.35 & & 14.23 & 14.78 & \\
\hline Local resident & 29.41 & 5.12 & & 15.56 & 22.17 & \\
\hline Occupation (\%) & & & $* * *$ & & & \\
\hline Autonomous worker & 17.76 & 20.30 & & 19.64 & 17.24 & \\
\hline Employed & 47.40 & 59.10 & & 52.87 & 59.61 & \\
\hline Retired & 12.73 & 7.46 & & 9.87 & 6.40 & \\
\hline Other occupations & 22.11 & 13.14 & & 17.62 & 16.75 & \\
\hline Visiting party (\%) & & & $* * *$ & & & \\
\hline Alone & 8.04 & 6.14 & & 7.21 & 6.90 & \\
\hline Couple & 34.51 & 38.45 & & 36.05 & 37.44 & \\
\hline Children & 13.90 & 37.57 & & 27.61 & 23.65 & \\
\hline Group & 43.55 & 17.84 & & 29.13 & 32.01 & \\
\hline Household annual income (\%) & & & $* * *$ & & & $* *$ \\
\hline $0-25,000$ & 19.57 & 9.28 & & 13.24 & 18.14 & \\
\hline $25,000-50,000$ & 39.13 & 26.52 & & 33.02 & 29.90 & \\
\hline $50,000-75,000$ & 11.71 & 15.36 & & 13.72 & 14.22 & \\
\hline$>75,000$ & 7.36 & 15.36 & & 12.96 & 5.88 & \\
\hline Missing income & 22.24 & 33.48 & & 27.06 & 31.86 & \\
\hline
\end{tabular}

Notes: $p$-value is the significance of the Chi-square test (qualitative variables), $z$-test (dichotomous variables), and $t$-test (quantitative variables). All test results are not significant unless indicated otherwise: ${ }^{* * *}$ Significant at $\mathrm{p} \leq 0.01,{ }^{* *}$ Significant at $\mathrm{p} \leq$ $0.05,{ }^{*}$ Significant at $\mathrm{p} \leq 0.1$

MART's visitors (Table 3) made their visits more during weekends (Friday, Saturday or Sanday), were more attracted by temporary showrooms and by the shop of the museum, even if the average expenditure (considering only the positive amount spent) is not significantly different to that stated by ÖTZI's visitors. They also participated more in other cultural activities in the city. People visiting ÖTZI were instead more interested in permanent collection.

In general temporary showrooms were significantly perceived as authentic. This indicates that the type of the exhibition hosted by the museum can of great importance for curators and managers in order to the perception of authenticity of the attraction. Table 3 also indicated that those who participated to other cultural activities proposed in the city felt the museum as more inauthentic. One implication of this is that the "culturally experienced" guest has a different perception of inauthenticity that can be influenced by the comparison, or even the competition, with other cultural attractions in the same area. Thus the coordination of policies by both municipalities' responsible in 
diversifying and properly managing cultural events, and museums managers in selecting temporary exhibitions, can be a key element for the improvement the perception of authenticity of the experience at the museum.

Table 3. Characteristics of the visit.

\begin{tabular}{|c|c|c|c|c|c|c|}
\hline & MART & ÖTZI & value & Authentic & Inauthentic $p$ & ralue \\
\hline Weekend (\%) & 50.84 & 39.28 & $* * *$ & 44.75 & 45.10 & \\
\hline Number of museums visited (mean) & 4.33 & 4.53 & & 4.50 & 4.26 & \\
\hline Permanent collections (\%) & 6.89 & 36.07 & $* * *$ & 21.60 & 23.27 & \\
\hline Temporary showroom (\%) & 34.29 & 21.41 & $* * *$ & 28.45 & 22.77 & $*$ \\
\hline Both permanent and temporary collections (\%) & 62.18 & 40.47 & $* * *$ & 50.52 & 53.96 & \\
\hline Other cultural activities (\%) & 8.77 & 3.99 & $* * *$ & 5.53 & 9.95 & $* *$ \\
\hline \multicolumn{7}{|l|}{ Expenditure at the shop of the museum } \\
\hline Positive expenditure (mean) & 11.40 & 8.97 & & 10.41 & 9.74 & \\
\hline Visit to the shop of the museum (\%) & 35.91 & 24.89 & $* * *$ & 30.77 & 27.23 & \\
\hline
\end{tabular}

Notes: $p$-value is the significance of the z-test (dichotomous variables) and $t$-test (quantitative variables). All test results are not significant unless indicated otherwise: ${ }^{* * *}$ Significant at $\mathrm{p} \leq 0.01,{ }^{* *}$ Significant at $\mathrm{p} \leq 0.05,{ }^{*}$ Significant at $\mathrm{p} \leq 0.1$

Table 4 compares the proportions of those who agreed to the questionnaire statements about authenticity, and of motivations for the visit.

Table 4: Proportions of agreement (\%).

\begin{tabular}{|c|c|c|c|c|c|c|}
\hline & MART & ÖTZI & $p$-value & Authentic & Inauthentic & $p$-value \\
\hline \multicolumn{7}{|c|}{ Do you agree with the following statements? } \\
\hline Just a tourist attraction & 10.44 & 19.40 & $* * *$ & 13.81 & 22.06 & $* * *$ \\
\hline Unique in the world & 28.69 & 71.21 & $* * *$ & 54.57 & 31.53 & $* * *$ \\
\hline A place that makes you think & 92.11 & 76.61 & $* * *$ & 85.46 & 75.49 & $* * *$ \\
\hline $\begin{array}{l}\text { A way to describe an historical } \\
\text { era }\end{array}$ & 87.23 & 93.08 & $* * *$ & 93.18 & 75.00 & $* * *$ \\
\hline A fascinating attraction & 90.10 & 88.54 & & 93.84 & 65.2 & $* * *$ \\
\hline An authentic attraction & 81.68 & 85.74 & $*$ & - & - & \\
\hline \multicolumn{7}{|c|}{ Why have you visited the museum today? } \\
\hline To satisfy curiosity & 25.59 & 51.16 & $* * *$ & 39.55 & 36.76 & \\
\hline Rest/Relax & 14.88 & 8.26 & $* * *$ & 11.16 & 13.73 & \\
\hline $\begin{array}{l}\text { A specific interest in such an } \\
\text { attraction }\end{array}$ & 70.07 & 49.28 & $* * *$ & 61.78 & 48.04 & $* * *$ \\
\hline $\begin{array}{l}\text { To accompany a friend/family } \\
\text { member }\end{array}$ & 14.05 & 11.88 & & 12.49 & 15.20 & \\
\hline To learn something new & 20.90 & 42.17 & $* * *$ & 33.77 & 24.51 & $* * *$ \\
\hline Something which one ought to do & 13.21 & 10.72 & & 13.21 & 4.90 & $* * *$ \\
\hline Doing something worthwhile & 17.89 & 17.83 & & 19.39 & 10.29 & $* * *$ \\
\hline To occupy some leisure time & 10.87 & 12.90 & & 11.45 & 15.69 & $*$ \\
\hline
\end{tabular}

Notes: $p$-value is the significance of the $z$-test on the equality of two proportions. All test results are not significant unless indicated otherwise: ${ }^{* * *}$ Significant at $\mathrm{p} \leq 0.01,{ }^{* *}$ Significant at $\mathrm{p} \leq 0.05,{ }^{*}$ Significant at $\mathrm{p} \leq 0.1$

In general the majority of the interviewees considers the museum as authentic (83.82\%). Such perception differs significantly between visitors of the two museums and ÖTZI seems to give a more authentic experience than MART. Such difference was explored 
more in depth. According to the literature the perception of authenticity was caught by the agreement of the respondent to six statements: i) the museum is merely a tourist attraction; ii) it is unique in world; c) it is a place that makes you think; d) it describes an historical era; e) it is a fascinating attraction; f) it is generally authentic. The survey used in this study asked the respondents to evaluate the degree of agreement with these statements in a dichotomous way, "Yes/No". Therefore, the response to the question $\mathrm{f}$ ) allowed us to cluster the sample in two subsets of people who perceived the museum as authentic or not ("authentic" vs. "inauthentic"), assuming that if a respondent did not evaluate the museum as "authentic", he/she perceived it as "not authentic".

Only the response to the statement "A fascinating attraction" resulted did not produce significant differences between MART and ÖTZI. As for the remainder, visitors considered MART as a place that makes the visitor think more than ÖTZI, whereas ÖTZI's authenticity is more frequently associated with its uniqueness in the world and with a way to describe an historical era. The item that is inversely related to authenticity, that is the statement of the museum as mere tourist attraction, reports the lowest frequencies for each museum. Nevertheless, it appears to differ significantly between the two museums, and is in a higher frequency for ÖTZI.

Table 4 also reports how frequently items agreed within the two groups of people stating that the visited museum was in general "an authentic attraction" and "an inauthentic attraction". As expected, this preliminary analysis suggests that inauthentic perception is more frequently related to the idea of the museum as a mere tourist attraction. All the remaining aspects (uniqueness, fascination, place for thinking and that which describes an historical era) are instead related to authenticity perception and reinforced it.

As regards the motives that led respondents to visit the two museums (push factors), having a specific interest and satisfying curiosity report the highest frequencies and significantly differ between the two museums. The former matters more for the visitor to MART, whereas the latter is more relevant for ÖTZI. MART's guests also consider the visit as a moment to relax, whereas visitors of ÖTZI are more interested in learning something new. No significant differences concern the remaining motivations.

Some motives result in discriminating between authenticity and inauthenticity perception. Visitors reinforce their authenticity if they have a specific interest in the museum, or in an attraction proposed by it, want to learn something new, consider the visit as something that one ought to do or worthwhile. On the other hand, inauthenticity 
perception of the museum seems to be associated with the perception of the visit as an activity that occupies some leisure time. Overall, this earlier evidence suggests that the "authentic experience" is related to a concrete interest in the museum and in the "cultural value added" provided to the visitor.

\section{Results}

As mentioned in previous sections, two groups of Logit models were estimated. The first group of models (Table 5), briefly called model $\mathrm{A}$ in the following, aimed at assessing the determinants of the authenticity perception for either the whole sample (AW) and each museum - MART (model AM) and ÖTZI (model AO). The second group (called model B in Table 6) investigated the effect of authenticity-related variables and a set of covariates on the choice of visiting to each museum. Also model B reports estimates for three subsets: the whole sample (BW), those who perceive the museum as authentic (BA) and inauthentic (BI). Model B supposed that the visitor decides to visit one specific museum of the two. The set of regressors was almost the same for each model. The description of the independent variables used is given in the Appendix.

Regression models were estimated using White's (1980) robust variance-covariance matrix in order to correct the possible heteroskedasticity of the error terms. The software STATA was used.

Model AW (Table 5) reported that the type of museum visited ("MART" variable) did not significantly affect the visitors' authenticity perception. Thus the considered art museum was not perceived as more authentic than the archaeological one and vice versa. Uniqueness, historical value, fascination, and "not a tourist attraction" were the factors that better represent authenticity in both museums. The perception of authenticity was inversely related to whether the respondent participated to other cultural activities, while it was directly influenced by a specific interest in it and thinking that the visit was worthwhile. Males and visitors from households with a high level of income showed a higher perception of authenticity. Occupational status of "Employed" was instead inversely associated to authenticity.

Table 5: Odds of Model A. 


\begin{tabular}{|c|c|c|c|}
\hline \multirow[b]{2}{*}{ Independent variables } & \multicolumn{3}{|c|}{ Authentic $(=1)$ vs. Inauthentic $(=0)$} \\
\hline & Whole sample ${ }^{\mathrm{AW}}$ & MART $^{\text {AM }}$ & ÖTZI $^{\mathrm{AO}}$ \\
\hline MART & $0.88(0.24)$ & - & - \\
\hline Weekend & $0.99(0.18)$ & $0.88(0.24)$ & $1.18(0.33)$ \\
\hline Number of museums visited & $1.00(0.02)$ & $1.03(0.04)$ & $0.97(0.02)$ \\
\hline Permanent collections & $0.78(0.3)$ & $0.65(0.35)$ & $0.67(0.45)$ \\
\hline Temporary showroom & $1.38(0.55)$ & $7.10(4.34)^{* * *}$ & $0.63(0.40)$ \\
\hline Both permanent and temporary collections & $0.95(0.39)$ & $4.18(2.67)^{* *}$ & $0.55(0.35)$ \\
\hline Other cultural activities & $0.51(0.16)^{* *}$ & $0.34(0.13)^{* * *}$ & $2.72(2.18)$ \\
\hline \multicolumn{4}{|l|}{ Why have you visited the museum today? } \\
\hline To satisfy curiosity & $1.07(0.21)$ & $0.95(0.29)$ & $1.39(0.40)$ \\
\hline Rest/Relax & $0.84(0.22)$ & $0.68(0.22)$ & $0.75(0.36)$ \\
\hline A specific interest in such an attraction & $1.43(0.27)^{*}$ & $1.26(0.35)$ & $1.81(0.53)^{* *}$ \\
\hline To accompany a friend/family member & $0.70(0.17)$ & $0.42(0.15)^{* *}$ & $1.54(0.70)$ \\
\hline To learn something new & $1.09(0.22)$ & $1.25(0.39)$ & $1.12(0.34)$ \\
\hline Something which one ought to do & $1.85(0.75)$ & $1.24(0.60)$ & $2.81(2.23)$ \\
\hline Doing something worthwhile & $1.91(0.58)^{* *}$ & $3.63(1.69)^{* * *}$ & $1.14(0.50)$ \\
\hline To occupy some leisure time & $0.64(0.18)$ & $0.35(0.13)^{* * *}$ & $0.95(0.47)$ \\
\hline \multicolumn{4}{|l|}{ Do you agree with the following statements? } \\
\hline Just a tourist attraction & $0.65(0.16)^{*}$ & $0.46(0.17)^{* *}$ & $0.8(0.27)$ \\
\hline Unique in the world & $2.2(0.48)^{* * *}$ & $1.4(0.40)$ & $3.18(0.94)^{* * *}$ \\
\hline A place that makes you think & $1.28(0.32)$ & $1.08(0.54)$ & $1.31(0.42)$ \\
\hline A way to describe an historical era & $2.41(0.64)^{* * *}$ & $2.07(0.78)^{*}$ & $2.83(1.39)^{* *}$ \\
\hline A fascinating attraction & $5.97(1.41)^{* * *}$ & $5.51(2.03) * * *$ & $6.00(2.44)^{* * *}$ \\
\hline \multicolumn{4}{|l|}{ Expenditures } \\
\hline Shop of the museum & $1.00(0.02)$ & $0.99(0.03)$ & $1.01(0.02)$ \\
\hline Missing shop of the museum & $1.08(0.23)$ & $1.46(0.47)$ & $0.77(0.27)$ \\
\hline \multicolumn{4}{|c|}{ Socio-demographic and economic characteristics } \\
\hline Male & $1.43(0.27)^{*}$ & $1.65(0.49)^{*}$ & $1.62(0.45)^{*}$ \\
\hline Age & $1.03(0.05)$ & $1.09(0.07)$ & $0.99(0.08)$ \\
\hline Age2 & $1.00(0.00)$ & $1.00(0.00)$ & $1.00(0.00)$ \\
\hline University & $1.00(0.22)$ & $1.17(0.40)$ & $1.17(0.37)$ \\
\hline Income & $1.01(0.00)^{* *}$ & $1.01(0.01)^{*}$ & $1.01(0.01)$ \\
\hline Missing income & $1.29(0.38)$ & $1.67(0.73)$ & $1.18(0.53)$ \\
\hline \multicolumn{4}{|l|}{ Origin of visitors } \\
\hline Abroad & $1.55(0.71)$ & $0.68(0.47)$ & $1.78(1.52)$ \\
\hline Germany & $1.25(0.43)$ & $1.87(1.35)$ & $1.05(0.76)$ \\
\hline Centre/South of Italy & $1.65(0.57)$ & $2.64(1.30)^{* *}$ & $1.55(1.26)$ \\
\hline North-East of Italy & $1.26(0.34)$ & $1.36(0.44)$ & $1.41(1.05)$ \\
\hline North-West of Italy & $1.09(0.35)$ & $1.18(0.52)$ & $0.90(0.69)$ \\
\hline \multicolumn{4}{|l|}{ Occupation } \\
\hline Autonomous worker & $0.77(0.27)$ & $0.75(0.43)$ & $0.64(0.33)$ \\
\hline Employed & $0.62(0.18)^{*}$ & $0.42(0.19)^{* *}$ & $0.72(0.31)$ \\
\hline Retired & $1.64(0.97)$ & $1.42(1.34)$ & $1.77(1.76)$ \\
\hline \multicolumn{4}{|l|}{ Visiting party } \\
\hline Alone & $1.44(0.55)$ & $1.35(0.68)$ & $0.86(0.58)$ \\
\hline Couple & $0.95(0.22)$ & $0.93(0.30)$ & $0.71(0.30)$ \\
\hline Children & $1.13(0.29)$ & $1.11(0.46)$ & $0.81(0.34)$ \\
\hline \multicolumn{4}{|c|}{$\begin{array}{l}\text { Notes: Robust standard errors in brackets. All test results are not significant unless indicated otherwise: }{ }^{* * *} \text { Significant at } \mathrm{p} \leq 0.01 \text {, } \\
\text { Significant at } \mathrm{p} \leq 0.05,{ }^{*} \text { Significant at } \mathrm{p} \leq 0 . \mathrm{AW}^{\mathrm{AW}} \mathrm{N}=1201 \text {; Wald } \chi^{2}(39)=169.98 \text {; Prob }>\chi^{2}=0 \text {; Log pseudolikelihood }=-428.947 \\
\text { McKelvey and Zavoina's } \mathrm{R}^{2}=0.299 \mathrm{AM} \quad \mathrm{N}=582 ; \quad \text { Wald } \chi^{2}(38)=103.42 ; \text { Prob }>\chi^{2}=0 ; \text { pseudolikelihood=-212.9097 } \\
\text { McKelvey\&Zavoina's } \mathrm{R}^{2}=0.367 \text { AO } \mathrm{N}=619 ; \quad \text { Wald } \chi^{2}(38)=105.72 ; \text { Prob }>\chi^{2}=0 ; \text { pseudolikelihood=-189.8319 } \\
\text { McKelvey\&Zavoina's } \mathrm{R}^{2}=0.365\end{array}$} \\
\hline
\end{tabular}

Table 6: Odds of Model B. 


\begin{tabular}{|c|c|c|c|}
\hline & \multicolumn{3}{|c|}{ MART $(=1)$ vs. ÖTZI $(=0)$} \\
\hline Independent variables & Whole sample ${ }^{\mathrm{BW}}$ & Authentic $^{\mathrm{BA}}$ & Inauthentic $^{\mathrm{BI}}$ \\
\hline Weekend & $1.69(0.32)^{* * *}$ & $1.68(0.36)^{* *}$ & $3.63(3.05)$ \\
\hline Number of museums visited & $1.01(0.02)$ & $1.02(0.02)$ & $0.92(0.07)$ \\
\hline Permanent collections & $1.25(0.59)$ & $1.02(0.60)$ & $104.11(203.50)^{* *}$ \\
\hline Temporary showroom & $4.78(2.37)^{* * *}$ & $9.55(6.24)^{* * *}$ & $1.55(1.52)$ \\
\hline Both permanent and temporary collections & $8.61(4.45)^{* * *}$ & $15.09(10.32)^{* * *}$ & $158.31(275.31)^{* * *}$ \\
\hline Other cultural activities & $1.54(0.52)$ & $1.15(0.43)$ & $134.77(268.95)^{* *}$ \\
\hline \multicolumn{4}{|l|}{ Why have you visited the museum today? } \\
\hline To satisfy curiosity & $0.64(0.14)^{* *}$ & $0.46(0.11)^{* * *}$ & $8.09(8.18)^{* *}$ \\
\hline Rest/Relax & $2.94(0.95)^{* * *}$ & $3.53(1.36)^{* * *}$ & $22.49(28.19)^{* *}$ \\
\hline A specific interest in such an attraction & $2.34(0.50)^{* * *}$ & $2.13(0.53)^{* * *}$ & $16.43(15.02)^{* * *}$ \\
\hline To accompany a friend/family member & $0.97(0.27)$ & $0.79(0.26)$ & $3.91(3.92)$ \\
\hline To learn something new & $0.42(0.09)^{* * *}$ & $0.34(0.08)^{* * *}$ & $2.27(2.14)$ \\
\hline Something which one ought to do & $1.70(0.44)^{* *}$ & $1.68(0.46)^{*}$ & $4.31(6.12)$ \\
\hline Doing something worthwhile & $1.38(0.39)$ & $2.12(0.71)^{* *}$ & $0.03(0.06)^{*}$ \\
\hline To occupy some leisure time & $0.63(0.18)$ & $0.49(0.16)^{* *}$ & $0.75(0.66)$ \\
\hline \multicolumn{4}{|l|}{ Do you agree with the following statements? } \\
\hline Just a tourist attraction & $0.76(0.23)$ & $1.06(0.38)$ & $0.15(0.14)^{* *}$ \\
\hline Unique in the world & $0.15(0.03)^{* * *}$ & $0.11(0.03)^{* * *}$ & $0.06(0.06)^{* * *}$ \\
\hline A place that makes you think & $3.07(0.96)^{* * *}$ & $3.02(1.05)^{* * *}$ & $34.98(40.44) * * *$ \\
\hline A way to describe an historical era & $0.35(0.13)^{* * *}$ & $0.50(0.24)$ & $0.13(0.12)^{* *}$ \\
\hline A fascinating attraction & $1.29(0.46)$ & $1.01(0.48)$ & $2.62(1.63)$ \\
\hline An authentic attraction & $1.03(0.32)$ & - & - \\
\hline \multicolumn{4}{|l|}{ Expenditures } \\
\hline Shop of the museum & $1.01(0.01)$ & $1.02(0.01)^{* *}$ & $0.98(0.06)$ \\
\hline Missing shop of the museum & $1.84(0.4)^{* * *}$ & $1.90(0.47)^{* * *}$ & $4.19(3.31)^{*}$ \\
\hline \multicolumn{4}{|c|}{ Socio-demographic and economic characteristics } \\
\hline Male & $1.15(0.22)$ & $1.04(0.23)$ & $2.84(2.36)$ \\
\hline Age & $0.97(0.04)$ & $0.93(0.05)$ & $1.22(0.33)$ \\
\hline Age2 & $1.00(0.00)$ & $1.00(0.00)^{*}$ & $1.00(0.00)$ \\
\hline University & $1.72(0.40)^{* *}$ & $1.63(0.44)^{*}$ & $0.89(0.54)$ \\
\hline Income & $0.99(0.00)^{*}$ & $0.99(0.00)^{* *}$ & $0.98(0.02)$ \\
\hline Missing income & $0.48(0.14)^{* *}$ & $0.45(0.15)^{* *}$ & $0.08(0.11)^{*}$ \\
\hline \multicolumn{4}{|l|}{ Origin of visitors } \\
\hline Abroad & $0.04(0.02)^{* * *}$ & $0.04(0.02)^{* * *}$ & $0.00(0.01)^{* *}$ \\
\hline Germany & $0.04(0.02)^{* * *}$ & $0.03(0.02)^{* * *}$ & $0.00(0.00)^{* *}$ \\
\hline Centre/South of Italy & $0.08(0.03)^{* * *}$ & $0.08(0.03)^{* * *}$ & $0.00(0.01)^{* * *}$ \\
\hline North-East of Italy & $0.63(0.20)$ & $0.62(0.23)$ & $1.16(0.90)$ \\
\hline North-West of Italy & $0.15(0.05)^{* * *}$ & $0.13(0.05)^{* * *}$ & $0.04(0.06)^{* *}$ \\
\hline \multicolumn{4}{|l|}{ Occupation } \\
\hline Autonomous worker & $0.56(0.20)^{*}$ & $0.70(0.27)$ & $0.01(0.01)^{* *}$ \\
\hline Employed & $0.54(0.15)^{* *}$ & $0.58(0.19)^{*}$ & $0.03(0.06)^{*}$ \\
\hline Retired & $0.58(0.29)$ & $0.61(0.36)$ & $0.00(0.01)^{* *}$ \\
\hline \multicolumn{4}{|l|}{ Visiting party } \\
\hline Alone & $0.35(0.13)^{* * *}$ & $0.40(0.16)^{* *}$ & $0.10(0.11)^{* *}$ \\
\hline Couple & $0.46(0.11)^{* * *}$ & $0.59(0.17)^{*}$ & $0.11(0.10)^{* *}$ \\
\hline Children & $0.14(0.04) * * *$ & $0.16(0.05)^{* * *}$ & $0.02(0.03)^{* * *}$ \\
\hline \multicolumn{4}{|c|}{ 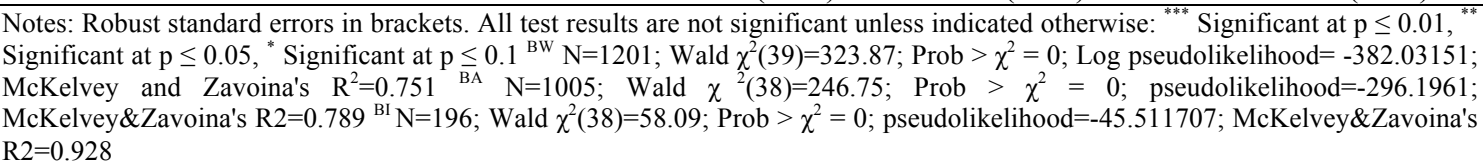 } \\
\hline
\end{tabular}

Variables significantly affecting the authenticity perception differ for each museum (models AM and AO), implying that this perception is influenced also by the characteristics of the visit experience. For both museums the authenticity perception 
was related to its fascination and to its capacity to describe a historical era. Elements of distinction concerned instead the perception of ÖTZI as authentic for its uniqueness in the world, and MART as "not a tourist attraction". In general, males had a higher authenticity perception of the experience lived for both museums.

From model AM (MART) it emerged that the dependent variable was directly related to the visit of the temporary showroom, or both temporary and permanent collections. Those who declared that visiting was something worthwhile perceived the museum as authentic. Visitors from households with a high level of income and visitors from Centre/South of Italy had also a higher perception of authenticity.

Model AO showed that the only other specific element of influence in the authenticity perception of ÖTZI was a specific interest on it.

For what concerns the perception of inauthenticity, MART is considered inauthentic by "Employed", and also by all who visit it to accompany a friend/family member or to occupy some leisure time. Finally, those who attended other cultural activities in the city of Rovereto or Trento consider the experience at the museum as inauthentic. Thus, as also reported in the description of the sample, the experience of other cultural activities and the comparison with them appears to affect the authenticity perception of the modern art museum.

Model BW (Table 6) shows that the choice of visiting a type of museum does not depend on the "rough" perception of the attraction as authentic. ÖTZI is instead felt as more authentic than MART due to its uniqueness in the world and the way it describes history, whereas MART is perceived as a place that makes the visitor think.

The results of models BA and BI highlighted that the choice between MART or ÖTZI, in the two subgroups of visitors "authentic" and "inauthentic", was significantly related to common elements, but at the same time peculiar variables characterizing each museum were found. Significant factors across all groups and with the same sign do not concur in discriminating the groups. These commonly influencing elements of both authentics and inauthentics in selecting MART were the visit of both permanent and temporary showroom, push factors as rest/relax and a specific interest in the attraction, authenticity of MART as place that makes thinking. The choice of ÖTZI for the two groups was instead related to its uniqueness in the world, origin from non-neighbour places, working as employed, and party typology with respect to visiting groups.

Peculiar traits of the "authentic" visiting MART were instead the visit during weekends and to the temporary showroom. As regards to push factors, it can be observed that 
MART was preferred to ÖTZI, in an authenticity perspective, when the visitor thought of it as something worthwhile and considered the visit as something one ought to do. On the other hand, the visitors saw ÖTZI more than MART as a chance to satisfy curiosity, learn something new, and occupy leisure time.

Among "authentic" visitors, the higher was the expenditure at the shop of the museum and the level of the education, the higher was the probability to visit MART. Preference to ÖTZI is instead associated to a higher income.

Within the "inauthentic" group, the visit to MART was associated to permanent exhibition and the attendance to other cultural activities. Among the push factors, the inauthenticity of the visit to MART concerned the satisfaction of a curiosity, whereas that of ÖTZI was instead significantly related to the visit for doing something worthwhile. Concerning the authenticity-related statements, the perception of inauthenticity of ÖTZI was related to considering the museum as a mere tourist attraction and a way to describe a historical era. Moreover autonomous workers and retired were likely to report that ÖTZI was not authentic.

\section{Discussions and conclusions}

The concept of authenticity is complex and no unique definition provides an exhaustive description. As pointed out by Culler (1988), authenticity is paradoxical thing because it always eludes us. As soon as we become reflexively aware, so that authenticity is something to be achieved or recovered, it is already lost. Cultural attractions are the ones where the perception of the "authentic" has a great importance, inasmuch as it contributes to characterize a place in time or space and provides to define its "identity". Indeed museums are the most important cultural attractions. The concept of authenticity itself was originally introduced in order to characterize museums. Both the concept and the role of the museum changed over time. The former was extended to the whole tourist product, whereas the latter from places aimed at educating visitors became cultural attractions. At the same time, as Cohen (1988) suggested, different people have different perspectives and needs. For example, there may be differences between those who felt they experienced the "real" culture and those who did not. Differences may concern also socio-demographic and economic variables. This has serious implications for heritage tourism, and therefore museum visits, inasmuch as their educational role is 
high. Knowing the profile of the cultural visitor, who feels an attraction as more or less authentic, becomes of great importance, since "the more learned, the more discriminating the tourist becomes" (Chhabra et al., 2003).

The approach followed by this paper was quantitative. It was based on direct survey of the perception of authenticity in two different types of museums. MART is a modern art museum, whereas ÖTZI mainly hosts the exhibition of an ancient mummy. Both are international attractions and are the most important museums of Trentino-South Tyrol, a region in the North-East of Italy. The museums provide very different experiences to visitors and consequently can lead to a different perception of authenticity. In addition to a direct question about the general perception of authenticity, five aspects of this concept were considered in this analysis: a) the museum is purely a tourist attraction; $b$ ) it is unique in world; c) it is a place that makes you think; d) it describes an historical era; e) it is a fascinating attraction. Two different perspectives were adopted for data analysis, both making use of Logit models. The first tried to assess the determinants of authenticity. The second one was aimed at testing the role of authenticity perception in the choice between two museums in a "potential" (and, in this paper, "virtual") competition.

Two-way tables results suggested that art museum visitors were more likely to have a higher level of education, to be retired or in other occupation (as students and teachers). This is consistent with what found by Bennett (1994) and Schuster (1991).

The results of Logit models indicated that both museums were perceived as authentic due to their "fascination" and their role of means to describe a historical era. This is consistent with the evolution of the role of museums in time, and also indicates that the educational value in reporting what emerges from the past persists somehow. The authenticity perception for MART was also related to the consideration that it is not a tourist attraction. As Kirshenblatt-Gimblett (1998) underlined, "tourism needs destinations, and museums are premier attractions" and "museums need visitors, and the tourism industry, more than the other sectors of economy, can deliver the hordes to museum doors". Therefore, it is important that the visitors consider the museum as a cultural attraction, and not as a mere tourist attraction, in order to allow them to maintain their authenticity perception of the experience at the museum. Consequently, the museums must present themselves as places where visitors can learn, discover, understand something, and enrich their own culture, rather than as spaces created in a destination in order to attract visitors. 
The authenticity perception of ÖTZI was instead associated to its uniqueness in the world. This is not surprising due the attention of scientists, and consequently of media, on the oldest and best preserved mummy in the world.

The art museum considered was appreciated for its temporary showrooms, whereas the permanent collection of archaeological museum was not able to give it a value of authenticity. Results suggested also that men had a higher "perception of authentic" of the museums than women, with no distinctions of the two analysed typologies.

Furthermore visitors living in high-income families considered the art museum as more authentic, but this factor did not influence the authenticity perception of the archaeological visitors. The origin of visitors was another important socio-demographic variable affecting the authenticity perception and that allowed discriminating between the two types of museums. Visitors coming from Centre-South or Islands of Italy considered the art museum as more authentic than the visitors who come from another place. The origin instead doesn't affect the authenticity perception of the archaeological museum. The Centre-South and Islands of Italy are rich in archaeological and historical sites, and less attention is paid to modern and contemporary museums. This suggests that the authenticity perception for MART visitors from this area of Italy can be linked to a novelty factor, i.e. it is authentic an experience that they cannot try at home.

Among visitors who considered the visited museum as authentic, the further the distance from the permanent residence, the higher the attraction towards the archaeological museum. Furthermore, people with an authentic view of the museum visited and with a higher education were more attracted to the art museum rather than the archaeological one. This result reinforces the above mentioned findings of Bennett (1994) and Schuster (1991).

Some interesting policy indications emerge from the empirical evidence. The perception of authenticity of the modern art museum seemed to be negatively affected by the visit of other cultural attraction in the town. At the same time the cultural value of the museum was not put under discussion, for there emerged a significant perception of it as "not a tourist attraction" and "a way to describe a historical era". These facts suggest the need to search for a unified and coordinated policy for local cultural attractions in the municipality, which would provide a greater value of authenticity to every place or event. Peculiar attention should also be paid to in promoting the museums to those places and communities that would perceive modern and contemporary art as novelties. In this sense the model indicated places in the Centre-South of Italy, where classical art 
is often the "natural landscape" of towns. This latter suggestion is worthy of more in depth study.

The archaeological museum instead appears to gain in authenticity perception from its uniqueness in the world and historical value. Over the years, appropriate promotional policies have been conducted through media in order to promote the high historical and archaeological value of the "iceman" and its importance for scientists. This process resulted being crucial to visitors' perception of the specific value of the museum. Nevertheless, this may also constitute a risk, as the group of "inauthentic" perceived ÖTZI as a mere tourist attraction. The excessive promotion and the marketing of museums as "products" might thus produce a loss of authenticity in visitors' perception. In addition to these qualitative findings, the promotion of museums should also consider the distributions of tourists according to their origin. In particular, MART should expand its promotion policies in order to attract visitors from foreign countries. This could be obtained by exploiting the particular characteristics of its temporary exhibitions that are considered unique. A policy more directed to the Italian market should instead characterize OTZI's efforts of promotion. This museum could attract more Italian visitors by focusing on the uniqueness that has been acknowledged in the rest of the world.

The main limitation of this study is that the econometric model performs estimates on a non-probabilistic sampling technique. Future investigations are required at other museums, years, and/or places in order to validate the above results. Nevertheless the results of this paper gave a theoretical contribution reinforcing most of the existing literature that claims that authenticity is a complex matter, its perception is subjective, and is founded on intrapersonal and interpersonal experience. In fact, cultural background, origin, and motivations affect the way authenticity is experienced and perceived. This causes archaeological and art visitors to have a different perception of authenticity. Furthermore, this study confirms that the perception of authenticity is a dynamic concept, in the sense that it changes on the basis of the audience and the phenomenon under observation. Further and more in depth research is recommended in order to better understand this issue. 


\section{References}

AAM (2000). American Association of Museums Code of Ethics for Museums (http://www.aam-us.org/museumresources/ethics/coe.cfm). Accesed on September $20,2012$.

Apostolakis, A. (2003). The convergence process in heritage tourism. Annals of Tourism Research, 30(4), 795-812.

Baudrillard, J. (1983). Simulations. New York: Semiotext Inc.

Belhassen, Y., \& Caton, K. (2006). Authenticity matters. Annals of Tourism Research, 33(3), 853-856.

Benjamin, W. (1968). The Work of Art in the Age of Mechanical Reproduction. In Illuminations, H. Arendt, ed., pp. 217-252. New York: Shocken Books.

Benjamin, W. (2008). The Work of Art in the Age of its Technological Reproducibility: Second version. In M. W. Jennings, B. Doherty, \& T. Y. Levin (Eds.), The Work of Art in the Age of its Technological Reproducibility, and other writings on media (pp. 19-55). Cambridge: The Belknap Press.

Bennett, T. (1994). The reluctant museum visitor: A study of non-goers to history museums and art galleries. Sydney: Australia Council.

Bennett, T. (1995). The Birth of the Museum: History, Theory, Politics. London and New York, Routledge.

Bonet, L. (2003). Cultural Tourism. In R. Towse (Eds.), A Handbook of Cultural Economics, 187-193. Northampron: Edward Elgar.

Brida J.G., Disegna M., \& Osti, L. (2012a), Authenticity Perception of Cultural Events: A Host-Tourist Analysis, Tourism Culture \& Communication, forthcoming Vol. 12. Brida, J.G., Osti, L. , \& Disegna, M. (2012c) The Effect of Authenticity on Tourists' Expenditure at Cultural Events. Current Issues in Tourism. DOI:10.1080/13683500.2012.674105

Brida, J.G., Pulina, M. , \& Meleddu, M. (2012d). An archaeological find fostering urban attractiveness: the case of the Ötzi museum in Bolzano. Journal of Travel Research 51(6): 727-738.

Brida, J.G., Pulina, M., \& Meleddu, M. (2012b). Factors influencing the intention to revisit a cultural attraction: the case of MART of Rovereto. Journal of Cultural Heritage 13(2): 167-174. 
Brown, S., Kozinets, R.V., \& Sherry, J., Jrl (2003). Teaching old brands new tricks: Retrobranding and the revival of brand meaning. Journal of Consumer Research, $67,19-33$.

Carnegie, E., \& McCabe, S. (2008). Re-enactment Events and Tourism: Meaning, Authenticity and Identity. Current Issues in Tourism, 11(4), 349-368

Chhabra, D. (2008). Positioning museums on an authenticity continuum. Annals of Tourism Research, 35(2), 427-447.

Chhabra, D. (2012). Authenticity of the objectively authentic. Annals of Tourism Research, 39(1), 499-502.

Chhabra, D., Healy, R., \& Sills, E. (2003). Staged authenticity and heritage tourism. Annals of Tourism Research, 30(3), 702-719.

Cohen, E. (1988). Authenticity and commoditization in tourism. Annals of Tourism Research, 15(3), 371-386.

Correia, A., Kozak, M., \& Ferradeira, J. (2011). Impact of Culture on Tourist Decisionmaking Styles. International Journal of Tourism Research, 13 (5), 433-446.

Culler, J. (1988). The semiotics of tourism. In Jonathan Culler 1988. Framing the Sign: Criticism and its Institutions. New York: Blackwell, pp 153-67.

Dicks, B. (2003). Culture on display: The production of contemporary visitability. Berkshire: Open University Press.

Graburn, N. (1983). The antropology of tourism. Annals of Tourism Research, 10(1), 933.

Graburn, N. (1998). A quest for identity. Museum International, 50(3), 13-18.

Hall, CM. (2007). Response to Yoeman et al: The fakery of 'The authentic tourist'. Tourism Management, 28(4), 1139-1140.

Handler, R. (1986). Authenticity. Anthropology Today, 2(1), 2-4.

Handler, R., \& Saxton, W. (1988). Dissimulation: Reflexivity, Narrative, and the Quest for Authenticity in "Liv- ing History". Cultural Anthropology, 3, 242-260.

Harrison, J. (2005). Shaping Collaboration: Considering Institutional Culture. Museum Management and Curatorship, 20(3), 195-212.

Hastrup, K., \& P. Hervik (1994). Social Experience and Anthropological Knowledge. London: Routledge.

Hede, A.M., \& Thyne, M. (2010). A journey to the authentic: Museum visitors and their negotiation of the inauthentic. Journal of Marketing Management, 26(7-8), 686705. 
Herreman, Y. (1998). Museums and tourism: Culture and consumption. Museum International, 50(3), 4-12.

Hughes, H. L. (2002). Culture and tourism: A framework for further analysis. Managing Leisure, 7(3), 164-175.

Kim, H., Cheng, C. K., \& O’Leary, T. J. (2007). Understanding participation patterns and trends in tourism cultural attractions. Tourism Management, 28(5), 1366-1371.

Kirshenblatt-Gimblett, B. (1998). Destination culture: tourism, museums, and heritage. London: University of California Press.

Kolar, T., \& Zabkar, V. (2010). A consumer-based model of authenticity: An oxymoron or the foundation of cultural heritage marketing? Tourism Management, 31(5), 652664.

Lau, R. W. K. (2010). Revisiting Authenticity. A Social Realist Approach. Annals of Tourism Research, 37(2), 478-498.

Leigh, T. W., Peters, C., \& Shelton, J. (2006). The consumer quest for authenticity: the multiplicity of meanings within the MG subculture of consumption. Journal of the Academy of Marketing Science, 34(4), 481-493.

Lennon, J., \& M. Graham (2001). Prognostication of the Scottish Culture and Heritage Sector's Skills Profile. Museum Management and Curatorship, 19(2), 121-139.

Lowenthal, D. (1990). Forging the past. In Fake? The Art of Deception, M. Jones, ed., British Museum, London, 16-22.

Lowenthal, D. (2005) The Past is a Foreign Country (New York: Cambridge University Press).

MacCannell, D. (1973). Staged authenticity: arrangements of social space in tourist settings. The American Journal of Sociology, 79(3), 589-603.

MacDonald, G., \& Alsford, S. (1995). Canadian Museums and the Representation of Culture in a Multicultural Museum. Cultural Dynamics, 7(1), 15-36.

Macdonald, S., \& Fyfe, G. (1996). Theorizing museums. Oxford: Black Publishers/The Sociological Review.

McIntosh, A. J., \& C. Prentice, R. (1999). Affirming authenticity: Consuming cultural heritage. Annals of Tourism Research, 26(3), 589-612.

McKercher, B. (2004). A comparative study of international cultural tourists. Journal of Hospitality and Tourism Management, 11(2), 95-107. 
McKercher, B., \& H. Du Cros (2002). Cultural Tourism: The Partnership between Tourism and Cultural Heritage Management. New York: Haworth Hospitality Press.

Naoi, T. (2004). Visitors' evaluation of a historical district: the roles of authenticity and manipulation. Tourism and Hospitality Research, 5(1), 45-63.

Olsen, K. H. (2002). Authenticity as a concept in tourism research: The social organization of the experience of authenticity. Tourist Studies, 2(2), 159-182.

Peterson, R. A. (2005). Search of authenticity. Journal of Management Studies, 42(5), 1083-1098.

Pine II, B.J., \& Gilmore, J.H. (2007). Museums \& authenticity. Museum News (May/June, 2007) http://www.strategichorizons.com/documents/MuseumNewsMay07-Museums\%26Authenticity.pdf. Accessed 08.09.12

Prentice, R. (2001). Experiential Cultural Tourism: Museums and the Marketing of the New Romanticism of Evoked Authenticity. Museum Management and Curatorship, 19(1), 5-26.

Ramkissoon, H., \& Uysal, M.S. (2011). The effects of perceived authenticity, information search behaviour, motivation and destination imagery on cultural behavioural intentions of tourists. Current Issues in Tourism, 14(6), 537-562.

Rickly-Boyd, J. M. (2012). AUTHENTICITY \& AURA. A Benjaminian Approach to Tourism. Annals of Tourism Research, 39(1), 269-289.

Rubridge, S., (1995). Does authenticity matter? The case for and against authenticity in the performing arts. In: P. Campbell, ed. Analysing performance: interpretations, issues, ideologies. Manchester: Manchester University Press, 219-233.

Schouten, F. (2007). Cultural tourism: between authenticity and globalization. In Cultural tourism: Global and Local Perspectives, Richards G., ed., The Haworth Press, Inc., 25-37.

Schuster, M. D. (1991). The audience for American art museums. National endowment for the arts research division report 23. Washington: NEA.

Selwyn, T. (1996). Introduction. In The Tourist Image: Myths and Myth Making in Tourism, Tom Selwyn, ed., Chichester: Wiley, 1-32.

Sharpley, R. (1994). Tourism, Tourists \& Society. Huntingdon, Cambridgeshire: ELM Spooner, B. (1986). Weavers and Dealers: The Authenticity of an Oriental Carpet. In The Social Life of Things: Commodities in Cultural Perspective, A. Appadurai, ed., Cambridge: Cambridge University Press. 195-235. 
Steiner, C. J., \& Reisinger, Y. (2006). Understanding existential authenticity. Annals of Tourism Research, 33(2), 299-318.

Stylianou-Lambert, T. (2011). Gazing from home: cultural tourism and art museums. Annals of Tourism Research, 38(2), 403-421.

Trilling, L. (1972). Sincerity and Authenticity. London: Oxford University Press.

Tsaur, S.-H., Y.-C. Chiu, \& C.-H. Huang. (2002). Determinants of guest loyalty to international tourist hotels-a neural network approach. Tourism Management, 23 (4), 397-405.

Tufts, S., \& Milne, S. (1999). Museums: A supply-side perspective. Annals of Tourism Research, 26(3), 613-631.

Wang, N. (1999). Rethinking authenticity in tourism experience. Annals of Tourism Research, 26(2), 349-370.

White, H. (1980), A Heteroscedasticity-Consistent Covariance Matrix Estimator and a Direct Test for Heteroscedasticity, Econometrica, 48(4), 817-838.

Wooldridge, J. M. (2001). Econometric Analysis of Cross Section and Panel Data, $\left(1^{\text {st }}\right.$ edition). The MIT Press Cambridge.

Xie, P.F., \& Wall, G. (2002). Visitors' perceptions of authenticity at cultural attractions in Hainan, China. International journal of tourism Research, 4(5), 353-366.

Yang, L., \& Wall, G. (2009). Authenticity in ethnic tourism: domestic tourists' perspectives. Current Issues in Tourism, 12(3), 235-254.

Yeoman, I. S., Brass, D., \& Mcmahon-Beattie, U. (2007). Current issue in tourism: the authentic tourist. Tourism Management, 28(4), 1128-1138. 


\section{Appendix}

Description of the explanatory variables.

\begin{tabular}{|c|c|}
\hline MART $^{*}$ & $1=$ visit to MART; $0=$ visit to ÖTZI \\
\hline Weekend & $1=$ interview made on Friday, Saturday or Sunday; $0=$ otherwise \\
\hline Number of museums visited & Number of visited museums in the last 12 months (discrete) \\
\hline Permanent collections & $1=$ visited the permanent collection $(\mathrm{s}) ; 0=$ otherwise \\
\hline Temporary showroom & $1=$ visited the temporary showroom; $0=$ otherwise \\
\hline $\begin{array}{l}\text { Both permanent and temporary } \\
\text { collections }\end{array}$ & $1=$ visited both permanent and temporary collections; $0=$ otherwise \\
\hline Other cultural activities & $1=$ attended other cultural activities in the city; $0=$ otherwise \\
\hline \multicolumn{2}{|c|}{ Why have you visited the museum today? } \\
\hline To satisfy curiosity & $1=$ Satisfying curiosity; $0=$ otherwise \\
\hline Rest/Relax & $1=$ Relaxing; $0=$ otherwise \\
\hline $\begin{array}{l}\text { A specific interest in such an } \\
\text { attraction }\end{array}$ & $\begin{array}{l}1=\text { Specific interest in such an attraction is an important factor; } 0= \\
\text { otherwise }\end{array}$ \\
\hline $\begin{array}{l}\text { To accompany a } \\
\text { friend/family member }\end{array}$ & $1=$ Came with a friend/family member; $0=$ otherwise \\
\hline To learn something new & $1=$ Learn something new; $0=$ otherwise \\
\hline Something one ought to do & $1=$ It is something one ought to do; $0=$ otherwise \\
\hline $\begin{array}{l}\text { Doing something } \\
\text { worthwhile }\end{array}$ & $1=$ Doing something worthwhile; $0=$ otherwise \\
\hline To occupy some leisure time & $1=$ Occupying some leisure time; $0=$ otherwise \\
\hline \multicolumn{2}{|c|}{ Do you agree with the following statements about the museum you visited? } \\
\hline Just a tourist attraction & $1=$ just a tourist attraction; $0=$ otherwise \\
\hline Unique in the world & $1=$ unique in the world; $0=$ otherwise \\
\hline $\begin{array}{l}\text { A place that makes you } \\
\text { think }\end{array}$ & $1=$ a place that makes you think; $0=$ otherwise \\
\hline $\begin{array}{l}\text { A way to describe an } \\
\text { historical era }\end{array}$ & $1=\mathrm{a}$ way to describe an historical era; $0=$ otherwise \\
\hline A fascinating attraction & $1=\mathrm{a}$ fascinating attraction; $0=$ otherwise \\
\hline An authentic attraction ${ }^{* *}$ & $1=$ an authentic attraction; $0=$ otherwise \\
\hline \multicolumn{2}{|l|}{ Expenditure } \\
\hline Shop of the museum & $\begin{array}{l}\text { Expenditure at the shop of the museum in Euros; } 0 \text { if respondents do not } \\
\text { state their expenditure (continuous) }\end{array}$ \\
\hline Missing shop of the museum & $\begin{array}{l}1=\text { respondent does not declare her expenditure at the shop of the } \\
\text { museum; } 0=\text { otherwise }\end{array}$ \\
\hline \multicolumn{2}{|c|}{ Socio-demographic and economic characteristics } \\
\hline Male & $1=$ male; $0=$ female \\
\hline Age & Age of the respondent (continuous) \\
\hline Age2 & Squared age of the respondent (continuous) \\
\hline University & $1=$ education level is university degree or postgraduate; $0=$ otherwise \\
\hline Income & $\begin{array}{l}\text { Central value of each income category (see the list reported in Table 2); } \\
0 \text { if the respondent does not declare her income (continuous) }\end{array}$ \\
\hline Missing income & $1=$ respondent does not declare her income; $0=$ otherwise \\
\hline \multicolumn{2}{|l|}{ Origin of visitors } \\
\hline Abroad & $1=$ Abroad (excluding Germany); $0=$ otherwise \\
\hline Germany & $1=$ Germany; $0=$ otherwise \\
\hline Centre/South of Italy & $1=$ Centre, South, or islands of Italy; $0=$ otherwise \\
\hline North-East of Italy & $\begin{array}{l}1=\text { North-East of Italy (excluding the province in which the museum is } \\
\text { located); } 0=\text { otherwise }\end{array}$ \\
\hline North-West of Italy & $1=$ North-West of Italy; $0=$ otherwise \\
\hline Local resident & $1=$ province that host the museum; $0=$ otherwise (reference category) \\
\hline \multicolumn{2}{|l|}{ Occupation } \\
\hline Autonomous worker & $1=$ autonomous worker; $0=$ otherwise \\
\hline Employed & $1=$ employed (full-time or part-time); $0=$ otherwise \\
\hline
\end{tabular}




\begin{tabular}{|l|l|}
\hline Retired & $1=$ retired; $0=$ otherwise \\
\hline Other occupation & $\begin{array}{l}1=\text { student/unemployed/housewife/working occasional or on } \\
\text { project/teacher/other; } 0=\text { otherwise (reference category) }\end{array}$ \\
\hline Visiting party & $1=$ alone; $0=$ otherwise \\
\hline Alone & $1=$ partner/spouse; $0=$ otherwise \\
\hline Couple & $1=$ children between 0 and 12 years; $0=$ otherwise \\
\hline Children & $\begin{array}{l}1=\text { friends/colleagues/organized group/other relatives; } 0=\text { otherwise } \\
\text { (reference category) }\end{array}$ \\
\hline Group &
\end{tabular}

Notes: ${ }^{*}$ This independent variable was included only in Model A for the analysis of the whole sample ${ }^{* *}$ This independent variable was included only in Model B for the analysis of the whole sample. 